\title{
DEVELOPMENT OF PRIORITY AREAS FOR IMPROVING THE REGIONAL ECONOMIC POLICY IN RUSSIA
}

\author{
BASHIROVICH Omar Ugurchiev', \\ ABUBAKAROVNA Malika Dovletmurzaeva², \\ VIKTOROVNA Oksana Zherdeva ${ }^{3}$, VASILIEVNA Alisa Olisaeva ${ }^{4}$, \\ BAYZETOVNA Ruzanna Schaplok ${ }^{5}$
}

\footnotetext{
${ }^{I}$ Management Department, Ingush State University (RUSSIA)

${ }^{2}$ State and Municipal Administration Department, Chechen State University (RUSSIA)

${ }^{3}$ Accounting Department, Kuban State Agrarian University named after I.T. Trubilin (RUSSIA)

${ }^{4}$ Accounting and Taxation Department, North-Ossetian State University named after K.L. Khetagurov (RUSSIA)

${ }^{5}$ Department of Industry and Project Management, Kuban State Technological University (RUSSIA)
}

\begin{abstract}
In the 90s of the XX century, at a meeting of the UN World Commission on Environment and Development, a decision was made on the need to find a new paradigm for the development of civilization. The report "Our Common Future" prepared by this UN Commission substantiated the principle of "sustainable development" as a progressive form of development of society. Its peculiarity lies in the fact that it will satisfy the needs of not only the modern generation of people, but, at the same time, it will not infringe on the ability of future generations to ensure their existence.

In the XXI century, it is recognized as a determining principle for the development of countries and regions. To begin implementing the sustainable development principle in the regions of the Russian Federation, it is necessary, first of all, to develop a sound long-term strategy for the actions of all participants in regional activities, taking into account the complex interaction between socio-economic, environmental and other factors.

In methodological terms, this is an extremely complex interdisciplinary problem that excludes any intuitive approaches.

In the era of the digital economy, a complex of modern methods of informatics and system analysis and computer tools is required to consider the above interactions in practically accessible and analyzable economic and mathematical models, provided with a reliable, timely and complete information base.

It should be especially noted that in recent years the emphasis of social development has shifted from the factor concept of economic growth to the significance of human role as a subject of economic activity with human social goals.
\end{abstract}

\section{Keywords: world economy, crisis, social development, regional economy, economic policy, socio-economic potential, sustainable development, competition}

\section{JEL: FOO}

UDC: $332.13(470)$

COBISS.SR-ID: 18192905

\section{Introduction}

Analysis of multidirectional processes of regional development and forecasting of a regional socio-ecological-economic system is always in the focus of attention of Russian and foreign researchers in the field of economics, sociology, geography, etc. [1], [2], [3[, [9]. 
Despite that a wide range of social development factors studied in the economic literature exist, nevertheless, there is still no single universally accepted interpretation of them [1], [8].

Of course, this situation actualizes the problems of a comprehensive analysis and diagnosis of sustainable growth factors for the regional economy in order to determine effective measures for their priority involvement. Based on this, we came to the need to develop new methodological approaches to the study of the essence, formation and development of the socio-economic potential of the region.

Potential reserves and other opportunities of the territory, especially its structure, geographical location, inertia of economic growth, etc. are considered as parameters for assessing the socio-economic potential of the region.

In many works on the subject under discussion, it is recommended to consider the volume and efficiency of production, the level of involvement of production capacities, competitiveness of products, susceptibility to organizational and technological innovations, the level of informatization, etc. to assess the production potential of the region.

However, many of these indicators still remain as wishes, because they cannot be estimated or measured in any way due to the lack of statistical data necessary for this in the reports of the Federal State Statistics Service of the Russian Federation. Technically, they can be obtained (and not always) in the course of sample surveys directly at the economic entities themselves.

The development of market relations, the liberalization of business activity conditions, etc. gave an impetus to a new understanding of the territorial socio-economic potential's essence as the ability of the regional socio-economic system to adapt and stably function in conditions of increasing competition. It seems to us that in modern realities it is advisable to consider the socio-economic potential of the region in the form of a complex characteristic that takes into account both the internal resources of the territory (a combination of material assets, technologies, personnel, etc.) and the specifics of the surrounding and internal market and managerial environment.

At the same time, the given goal of studying the socio-economic potential of the region is of particular importance, because it predetermines the choice of the integral (generalizing) indicator and the analysis method itself.

\section{Research Methodology}

The theoretical and methodological basis of the research was the scientific papers and research results of Russian and foreign scientists in the field of management theory, sustainable development of the regional economy on the assessment and forecasting of regional trends in the development of the socio-economic potential of the territory.

The methodological base of this study is represented by fundamental methods of scientific knowledge, including such as system analysis, dialectical unity of qualitative and quantitative assessment, etc.

In the process of forming the formulated theoretical principles, conclusions and recommendations, a number of methodological tools and methods were used, including such as economic and statistical ones, systemic and structural analysis, forecasting, grouping, and generalization.

\section{Research Results}

In the course of the evolutionary development of mankind, the search for optimal ways of social development has never stopped under any circumstances. However, we must admit that the modern stage is the most dramatic, for humanity has realized that it is on the verge of a 
global catastrophe and self-destruction while maintaining the current principles and characteristics of the traditional path of its development, which requires a new development paradigm.

For humans, the habitat system has historically expanded through the complication of the structure of the human community itself, and over time an incomparably more complex system has developed that is called society. We consider it appropriate to recall the dictum of the already not fashionable in Russia, but, nevertheless, outstanding classic of political economy K. Marx: "Society is a historically developing set of relations between people that takes its shape in the process of their joint activity". [5]

In the course of our study, we found that the greatest difficulty in a comprehensive assessment of the socio-economic potential of a region is to establish the most characteristic and relatively independent statistical indicators and develop principles of their comparability to create a system of criteria that allow an objective assessment of the situation in question.

When analyzing the degree of regional development, first of all, the GDP (gross domestic (regional) product) is considered. Indeed, although with some convention but nonetheless, it integrates the final results of all types of activities that together create added value. Moreover, the algorithm for solving this problem consists of the following steps:

1. The formation of the necessary information base, a set of parameters and indicators;

2. Factor analysis of spatial development;

3. Solving the problems of constructing a typology of objects;

4. The solution of dynamic systems typology problems.

Moreover, any methodology must comply with a number of requirements, such as adaptation to the existing system of statistical indicators; it also must objectively disclose the position and significance of regional development factors, taking into account the interests of society and business structures.

It must be admitted that in practice we often deal with difficultly formalized indicators, and even with those for which there is no proper information base. In other words, most of the proposed methods are not suitable for wide replication and use ... [7], [12], [14]

Undoubtedly, in these conditions, the possibility of using tools for assessing the regional policies of foreign countries is even more complicated. In addition to the above, a lot of problems affect this, beginning from the need to improve the constitutional and legal provisions of federal relations and up to establishment of the level and methods of state participation in the economy, and to the system of strategic management of business entities.

In the current period of regional development of the Russian Federation constituent entities, the most effective instrument of regional economic policy is inter-budget transfers.

Initially, the regions received the right to receive a transfer in need of support when their per capita budget income was less than the average per capita budget income in all regions of the Russian Federation. However, due to the fact that the per capita incomes of regions were considered without appropriate adjustment for the prevailing regional prices, this made it impossible to compare regional and average per capita incomes in the country.

This situation made it possible to argue that such a transfer is nothing more than a simple subsidization of the regions without any connection with the actual level of public needs for public services.

Other examples can be cited, confirming that the current financing mechanisms used for the socio-economic equalization of the regions do not solve many problems of financing the expenses of the constituent entities of the Russian Federation.

Another problem is that the number of targeted federal target programs does not correlate with federal funding opportunities. [10]

All this requires the distribution of financial support for the regions through the development of special budgetary standards for financing costs. Such an approach will ensure 
the necessary minimum of state social standards and social norms for solving the main problems of local importance, taking into account the actual possibilities of the consolidated budget of the Russian Federation for their targeted financing in a current financial year.

For depressed territories, including depressed republics of the North Caucasus, a permanent federal budget deficit and an acute shortage of own funds for the mundane tasks of implementing any component of the regional socio-economic policy is always extremely problematic [11], [13].

But on the other hand, it is also necessary to recognize on the ground the need to find domestic resources to pursue their own economic policies, as well as large-scale attraction of investors.

Today, in all constituent entities of the Russian Federation, their own regional economic policies have been formed and are being implemented, including with elements of investment activity. To this end, local legislation has been developed and adopted to regulate investment activities; a mechanism has been proposed for providing incentives to investors (within their powers); special structures have been created to enhance investment processes, etc. [2]

We have to admit that the geopolitical situation and a number of ethnic conflicts in the region do not allow the depressed republics of the North Caucasus to receive the necessary impetus to mobilize foreign investors. There is not even a single financial-industrial group in the republics.

Under these conditions, it is also not necessary to talk about the existence of effective relationships between interregional economic structures and constituent entities of the Russian Federation. They are simply absent there.

In the course of our study, we noted that such a component of the regional economic policy as effective property management, reorganization of enterprises, and the development of the local stock market are poorly involved. To this end, it is advisable to create a special investment company in the republics of southern Russia to promote investment there. Its competence may include such procedures as initial preparation, examination of investment projects, and organization of internal and external investment.

It should be noted that all the depressed republics of the North Caucasus are agrarianoriented, labor-surplus and land poor regions, which at the same time have a rather solid potential for agro-industrial development. In these conditions, it is advisable for regional authorities to concentrate all resources on the creation of new structures in district, republican and interregional chains "production - storage - advanced processing - implementation insurance".

The regional agro-industrial policy should be focused on the constructive transformation of the sectoral structure of agro-industrial production and meet the real needs of the domestic market as the main consumer of agro-industrial products.

At the current stage, among the most priority areas for the implementation of agricultural policy in the republics it is necessary to note the need to provide sufficient state support to the agricultural processing sector, assistance in attracting investments, legislative determination of privileges for supporting enterprises to pay taxes to regional budgets, etc.

It seems to us that it is necessary to stop the transfer of authority without proper funding and attempts to solve social and economic problems only in federal structures, and not to use their own powers. The efforts being made to stimulate economic growth and many investment processes in depressed republics are virtually disappearing due to lack of funds.

Under these conditions, it is necessary to launch as soon as possible a new reproduction mechanism ensuring effective interaction between micro and macro levels of the economy and the transition to a policy of sustainable economic growth in order to ensure expanded reproduction of resources. It seems to us that the mechanism under consideration, in contrast to the current one, will orient not as usual to temporary financial stabilization, but to 
increasing the value of public and private assets, including also human capital in the long run. In other words, it is intended for the integrated development of the socio-economic potential of the regions in almost all areas.

\section{Conclusions and Proposals}

1. An analysis of the results of ongoing regional economic programs showed that in today's realities there is another problem, besides the acute shortage of funds: the inability to form and choose the goals of regional economic policy on the ground.

2. It has been established that the current mechanism for implementing regional economic policy, as a rule, is aimed at supporting existing production capacities, although it would have been more necessary to direct them to restructuring.

3. It seems to us appropriate, when implementing federal investment programs, to move away from the sectoral principle to the territorial-sectoral one. This will allow for more effective implementation of an active agro-industrial policy and restructuring of business entities.

4. In our opinion, when developing regional economic policies in labor-intensive depressive republics, it is necessary to take into account the economic activity of the private sector and its potential. Regions need to learn how to use it as an effective internal resource.

5. For the effective implementation of the regional socio-economic policy in the depressed republics of the North Caucasus, it is necessary to achieve its harmonious combination with agro-industrial, tourist-recreational and structural policies, coupled with a range of measures for the cost of small business.

\section{REFERENCES}

[1] Aganbegyan A.G. Socio-economic development of Russia: analysis and forecast // Problems of forecasting. 2014. No. 4., pp. 3-16.

[2] Animitsa EG Regional policy: essence, main goals, and problems // Regional Economy. 2015. No. 1, pp. 7-19.

[3] Gelbraith, J. K. Economic Theories and Goals of Society / Translation from English - M.: Progress, 1976.

[4] Gerasimov V.O., Sharafutdinov R.I., Kolmakov V.V., Erzinkyan E.A., Adamenko A.A., Vasileva A.G. Control in the human capital management system in the strategy of innovative development of a region. Entrepreneurship and Sustainability lssues. 2019. T. 7. № 2., pp. 1074-1088.

[5] Karl Marx. Capital. V.1. A Critique of Political Economy, 1867.

[6] Kolupaev A.A., Voronkova O.Yu., Vakhrushev I.B., Adamenko A.A., Solodkin V.S., Alekhina N.A. Corporate identity of lodging establishment as a factor of increasing tourism activity in the region. Proceedings of the $33^{\text {rd }}$ International Business Information Management Association Conference, IBIMA, 2019: Education Excellence and Innovation Management through Vision 2020, pp. 7948-7956.

[7] Makarov V.L. Historical examples of various methods of salvation from the crisis // Economic and social changes: facts, trends, forecast. 2011. V. 13. No. 1., pp. 29-36.

[8] Minakir P.A. Spatial interdisciplinary synthesis: the experience of program research // Region: economics and sociology. 2014. No. 4., pp. 3-31.

[9] Samuelson P. About what economists think? Conversations with Nobel laureates. M.: Alpina Business Books, 2009., p. 489.

[10] Yasin E.G., Jacobson L.I. Will there be a new model of economic growth in Russia? // Issues of economics. 2013. No. 5., pp. 4-39.

[11] Misakov V.S., Misakov A.V., Tsurova L.A., Adzhieva A.Yu., Eskiev M.A. Ways of improving the economic mechanism for the social development of rural settlements of mountainous areas//International Journal of Advanced Biotechnology and Research. 2017. V. 8. № 4., pp. 964-972.

[12] Misakov V.S., Tsurova L.A., Yandarbieva L.A., ThamadokovaI.Kh., Goigova M.G. Certification of regional economic complex as a highly effective tool for analysis and diagnostics of its development // Amazonia Investiga. 2019. V. 8. № 20., pp. 451-458. 
[13] Misakov V.S., Khamzatov V.A., Temrokova A.Kh., Misakov A.V., Dikareva I.A. Strategic management of innovative agro-industrial projects // Amazonia Investiga. 2018. V. 7. № 14, pp. 16-23.

[14] Ugurchiev O.B., Dovtaev S.A.Sh., Misakov V.S., Misakov A.V., Temmoeva Z.I., Gyatov A.V. Transition mechanism development to the sustainable balanced development of depressive territories // The Turkish Online Journal of Design Art and Communication. 2018. V. 8. № S-MRCHSPCL., pp. 248-253.

\section{Article history:}

Received 26 February 2020

Accepted 10 May 2020 